\title{
AC 2011-1341: UTILIZING BRIDGES ACROSS COLLEGES TO PROPOSE A GRANT TO IMPROVE THE RECRUITMENT AND RETENTION OF STUDENTS WITH DISABILITIES IN STEM PROGRAMS
}

\section{Donald C. Richter, Eastern Washington University}

DONALD C. RICHTER obtained his B. Sc. in Aeronautical and Astronautical Engineering from The Ohio State University, M.S. and Ph.D. in Engineering from the University of Arkansas. He holds a Professional Engineer certification and worked as an Engineer and Engineering Manger in industry for 20 years before teaching. His interests include project management, robotics /automation, Energy Management and air pollution dispersion modeling

\section{William R. Loendorf, Eastern Washington University}

William R. Loendorf is currently a Full Professor of Engineering \& Design at Eastern Washington University. He obtained his B.Sc. in Engineering Science at the University of Wisconsin - Parkside, M.S. in Electrical Engineering at Colorado State University, M.B.A. at the Lake Forest Graduate School of Management, and Ph.D. in Engineering Management at Walden University. He holds a Professional Engineer license and has 30 years of industrial experience as an Engineer or Engineering Manager at General Motors, Cadnetix, and Motorola. His interests include engineering management, technological literacy, improving the competitiveness of American companies, and real-time embedded systems.

Dr. Romel W. Mackelprang, Eastern Washington University

Director, Center for Disability Studies \& Universal Access 


\title{
Utilizing Bridges Across Colleges to Propose a Grant to Improve the Recruitment and Retention of Students with Disabilities in STEM Programs
}

\begin{abstract}
This paper describes how a collaborative interdisciplinary approach between the School of Social Work and Disability and the College of Science, Health \& Engineering developed a project proposal for a National Science Foundation grant that is intellectually and academically sound in its multi-tiered approach. It promotes the success of students with disabilities through direct interventions that encourage secondary students to consider Science, Technology, Engineering and Math (STEM) careers. The paper discusses how the proposed project would combine typical disability support services with comprehensive supports that involve peer mentoring by STEM students and faculty, academic advising, with a multidisciplinary team, to promote student recruitment and retention. The proposed multidisciplinary team would include faculty from the School of Social Work and Disability with Faculty of STEM fields such as Engineering and Engineering Technology. The paper also discusses how it proposes to utilize the University's Center for Disability Studies and Universal Access and curriculum for students to embrace their uniqueness as disabled persons in a manner similar to ethnic and women's programs. Further, it has practical implications on the teaching environment by offering pedagogical training relative to universal education to STEM faculty. In the past, many universities have proposed projects that have exposed students with disabilities to STEM career possibilities. The paper details how the proposed project will actively involve interdisciplinary partners from disability support services in a shared alliance with STEM faculty breaking down the silos that often lead to a disconnect for student success and retention. Educating not only how the disabled student can pursue a career in STEM, but educating the STEM faculty on how they can make their courses more universal in access is also important.
\end{abstract}

\section{Introduction}

This enrichment project will increase participation and success of students with disabilities at Eastern Washington University (EWU) in the fields of Science, Technology, Engineering and Mathematics (STEM). It will focus on recruiting high school and community college students with disabilities to enroll in STEM at EWU and at other institutions of higher education located in the Pacific Northwest. Each incoming EWU student with a disability will be offered mentoring to assist in transitioning to higher education. In addition, individualized academic support, financial advising and counseling, in partnership with the Washington Division of Vocational Rehabilitation (DVR), will be available and encouraged for all students. Subsequently, through an existing independent EWU project, these students attending regional institutions of higher education and in their final year of college in the region will be offered intensive services to facilitate transition to work upon graduation.

The intellectual merit of this project is its building on the unique partnership between two academically diverse EWU units; the Department of Engineering \& Design (E\&D) located 
within the College of Science, Health \& Engineering (CSHE) and the Center for Disability Studies and Universal Access (CDSUA), located within the College of Social and Behavioral Sciences (CSBS). The CSHE is the largest college at EWU with approximately 1,800 majors and 500 graduates per year. In contrast, the Center for Disability Studies and Universal Access (CDSUA) was created in 2006 to meet the needs of students with disabilities who come from the same social and economic backgrounds as other EWU students. CDSUA employs a social/diversity model of disability rather than the traditional medical/pathology based approaches. It focuses on environmental accessibility rather than ameliorating individual pathology. Since the creation of CDSUA, these units have partnered in multiple learning projects. For example, they collaborated on the design and construction of low cost accessible desks for students with mobility impairments. Results of their activities have been presented at professional conferences and submitted for professional publication (Loendorf, Richter, \& Teachman $\left.^{8}, 2010\right)$.

On a broader scope, the proposed project also strengthens collaboration between multiple student service entities including Disability Support Services, Academic Advising, First Year Experience, Counseling and Psychology Services, and Eagle Advantage (an EWU program for students at high risk of dropping out of college including first generation, disabled, low income, and ethnic minority students). These relationships were developed in large measure from a grant from Washington State to facilitate successful transitions to college for at-risk students including students with disabilities (CDSUA $\left.{ }^{6}, 2008 ; \operatorname{CDSUA}^{5}, 2009\right)$.

EWU has become an institution of opportunity for many college students who may have otherwise not attended college. EWU serves the highest proportion of low-income, first generation students than any other four-year institution of higher education (IHE) in eastern Washington, a region with many low-income and struggling families (United States Census Bureau $\left.^{14}, 2007\right)$. These students are at increased risk of failure in higher education (Campbell \& Campbell $^{4}$, 2007; Washington Economic Development Commission ${ }^{15}$, 2004). Further, research has revealed that students with disabilities in Eastern Washington are at significantly greater risk of unsuccessful transitions from high school to college and then to the workplace than those without disabilities. (Mackelprang \& Altshuler', 2004; Altshurer, Mackeiprang, \& Baker ${ }^{1}, 2008$ ).

This project utilizes the Universal Education Access (UEA) approach developed at EWU and targets students with disabilities. The broader impact of the project for EWU is that UEA promotes the success of students from all backgrounds. UEA moves a step beyond reasonable accommodation and affirmative action by employing universal access for both typical and atypical people from the outset. In contrast, reasonable accommodation and affirmative action attempts to eliminate barriers and redress inequities that people have experienced (Burgstahler \& Cory $^{2}$, 2008; Lam, Doverspike, Zhao, \& Menzemer ${ }^{7}$, 2008; Mackeiprang \& Salsgiver ${ }^{10}$, 2009; Melber \& Brown ${ }^{11}$, 2008; Moriarty ${ }^{12}$, 2007).

As a result of collaboration, a review of EWU student records revealed that, in Spring 2008, only 16 of 1,798 STEM majors at EWU were students with disabilities (0.89\%). Comparatively, 62 of approximately 4,763 declared majors at EWU are students with disabilities (1.3\%); showing a greater than $60 \%$ difference. Thus, an obvious need immerged. This project was developed to 
address the gap and to increase the numbers of students with disabilities who enroll and successfully complete STEM majors.

\section{Project's Merits}

A primary merit of this project is the recruitment of high school students with disabilities to enroll in STEM courses and eventually enroll in STEM majors. It will also recruit community college students with disabilities to major in STEM at EWU or other four year institutions. Project staff will meet and consult with representatives of each school district. The project will conduct an annual, one-day STEM Fair at EWU and sponsored by EWU, Washington State University (WSU), Community Colleges, and Gonzaga University. Students with disabilities and their parents will participate in hands-on demonstrations in activities such as robotics, astronomy, and design. This visit to the university campus will be an opportunity to demystify the college experience for the potential students. STEM teachers from the high schools will also be invited to participate. A unique aspect of these Fairs will be involvement of academic programs from multiple colleges. In addition, student services personnel from each IHE will consult with and advise students and their parents. Fair participants will also be informed of the EWU peer mentoring program that will be provided to any attendee who enrolls at EWU. In addition, project personnel will be available to meet with students and educators subsequent to Fairs.

This project will also contribute to the success of students with disabilities who major in STEM or enroll in STEM courses. CDSUA will provide peer mentors for these students through its peer mentoring program. Peer mentors from the Disability Studies peer mentoring class will be paired with students with disabilities, with an emphasis on matching them with STEM mentors. Mentors will provide support and will assist mentees to navigate the college environment. Mentees will be recruited to become mentors for future students. Project faculty will monitor enrollment and performance and will provide academic advising and mentoring for participants. A unique merit of the project is the program initiated by CDSUA in academic year 2009-10. This program connects students with the Disability Support Services office to ensure they receive reasonable accommodation. It also helps students apply for state vocational rehabilitation services. In fall 2009, this program resulted in approximately 15 students with disabilities receiving services for the first time, resulting in $\$ 67,000$ in financial assistance. These support activities will result in improved academic success, including class grades.

In the long term, students who participate in the STEM project will be able to take part in a unique School to Work Transition Program (SWTP) in their final year of study. SWTP is a collaborative job-readiness project between EWU and the Washington Division of Vocational Rehabilitation and is codified by an interlocal agreement. The SWTP program provides career assistance, including internships and job placement services for STEM students with disabilities prior to and after graduation. Training relative to disability disclosure, worksite accommodations, and job-seeking skills is also provided to program participants. The program addresses issues that often surface during this critical transition from school to employment. In its first quarter, 9 EWU students with disabilities were referred to federal government agencies to engage in paid internships. Managed by EWU, the SWTP is provided to students at other IHEs as well. 
The multidisciplinary nature of this project is noteworthy. Project leaders hailing from "hard" sciences are collaborating with social science and human service faculty in the pursuit of enhanced student education and university climate. Participant CSHE and CSBS faculty will promote universal education access within and between their respective academic units. STEM faculty participants will promote Access For All training and principles to CSHE in which STEM programs reside. They will also recruit STEM faculty to participate in STEM Fairs, thus exposing them to students with disabilities. It is anticipated that previous research results relative to student performance will be replicated by new STEM faculty who complete workshops. Increased exposure will also facilitate greater STEM participation for students with disabilities.

\section{Collaboration}

This project provides a foundation for a future National Science Foundation Alliance Building program. To ensure project success, and prepare for an Alliance, the project will leverage EWU partnerships to develop and enhance multiple relationships. In the first year, it will connect with each school district in Spokane County and in communities within a two hour drive from Spokane, Washington to recruit faculty and students to participate in STEM Fairs. In addition, relationships will be developed and strengthened with Spokane Community College and Spokane Falls Community College that are a major student pipelines for EWU. In the 2008-09 school year, 356 students transferred to EWU from these two institutions, constituting the largest source of new EWU students. In the second year, relationships will be forged with school districts and community colleges in the central valley of eastern Washington; a vast area that runs from Yakima in the west to the Tri-cities and Walla Walla in the east, as well as with Central Washington University in Ellensburg, WA.

The project forges ongoing alliances between EWU and other institutions of higher education (IHEs) including the Community Colleges of Spokane, Washington State University, and Gonzaga University to promote universal education access, to encourage disabled youth to consider STEM careers in eastern Washington. Students with disabilities will be exposed to and encouraged to enroll in STEM programs at their respective institutions. It will provide the seed resources for long term partnerships on four levels that will be germinated in future NSF Alliance building grant projects:

- Institutions of higher education (IHEs): EWU will coordinate collaboration with the Community Colleges of Spokane, Gonzaga University (GU), Washington State University (WSU) to recruit students with disabilities to STEM majors. EWU will provide Access For All curriculum and training for partner IHEs. THE faculty and student services staff will be invited to recruit students with disabilities.

- EWU will collaborate with at least six school districts in eastern Washington and northern Idaho. Project staff will work with administrators and faculty from the districts to educate students about STEM and to recruit students to attend STEM Fairs.

- EWU will continue to partner with the Washington Division of Vocational Rehabilitation (DVR) to promote partnerships in business and industry. These activities occur on two levels. First, EWU co-sponsors quarterly meetings with business owners and leaders. Second, EWU has an interlocal agreement in place with DVR to work with DVR clients in the last year of their studies to prepare them for employment through activities such as resume building and internships. These partnerships are ancillary to this proposed NSF grant and is a retention 
resource for students with disabilities who can look forward to using this resource as they near graduation.

- EWU will partner with the Washington State Independent Living Council and the Coalition of Responsible Disabled in their youth transitions programs that target high school youth with disabilities to prepare them for transitions to adulthood.

\section{Project Description}

In the project's first year, the project principle investigators plan to convene the STEM Steering Committee. It will consist of the university and its partners and will recruit high school students to explore STEM majors. It will also recruit community college students to transfer to four-year institutes of higher education (IHE) to explore STEM majors at the region's universities. The committee will meet quarterly and will develop sub-committees to work on specific projects and assessments. Participants will include faculty and student services representatives for each IHE, a representative from each school district, DVR counselors, business representative, and Coalition of Responsible Disabled State Independent Living Council administrator. The Steering Committee will utilize information from the project's independent evaluator to guide in decision making and strategic planning.

The STEM Steering Committee will develop student recruitment and educational materials that will be shared with education and community partners. It will also plan the inaugural Inland Northwest STEM Fair, which will be held on the university's main campus, in which students with disabilities from throughout eastern Washington and northern Idaho will be invited to participate. Recruiting students with disabilities is especially important, as these students are rarely encouraged to participate in STEM fields of study (Burgstahler ${ }^{3}$, 1994). Project staff and partners will recruit by visiting target sites and by inviting people to attend a STEM Fair that will be held at the university.

The STEM Fair will be a one-day event in which university and other IHE STEM faculty will provide hands-on demonstrations that directly involve students in activities pertinent to specific STEM disciplines. Educational modules will include engineering, biology, geology, physics, biochemistry, computer science, and astronomy. In addition, computer workstations, equipped with extant assistive technology, will be set up for STEM Fair participants to experience firsthand. Student services representatives for IHEs will provide information about STEM programs at their respective institutions for students. STEM Steering Committee members and project staff will also recruit faculty and staff to accompany students or otherwise participate in the Fair. Local attendees will be invited to attend individually and project personnel will help organize school sponsored field trips for those who reside at a distance. The project will obtain continuing education credits for educators who need continuing education for licensure. Project STEM faculty and CDSUA staff will be available to consult with these educators relative to applicable STEM educational pedagogies (as well as universal education access in general), student services, and resources at their respective institutions, and to persuade them to encourage students with disabilities to consider studying STEM in college.

In the project's first year, key personnel will convene an internal STEM Advisory Committee of leaders from within the university. Members will be drawn from academic services, student 
services, and administration; thus promoting campus wide integration of the project's goals and activities. Other key members will include representatives of the administration of the college of Science, Health\& Engineering (CSHE) and the college of Social and Behavior Studies (CSBS), the Dean of Students office, Vice President for Student Services Office, Disability Support Services, Recruitment Office, Academic Advising, Counseling and Psychology Services, TRIO programs, and three EWU programs - Eagle Advantage, First Year Experience, and Eagle Scholars - that serve "at-risk" university students (e.g. low income, first generation, disabled, and racial and ethnic minorities). A linchpin of this project is the established alliances among multiple academic departments and between academics, student services, recruiters, and administration.

The project will build on the current faculty collaborations between CDSUA and E\&D. PI's will recruit University STEM faculty to participate in Access For All trainings that directly apply principles of Universal Education Access to STEM, including strategies identified by Melber \& Brown ${ }^{11}$ (2008) such as providing alternative assessment strategies, integrating objects and specimens, and preparing for accessibility. This will enhance their ability to provide a supportive educational atmosphere for students with disabilities, as well as other students.

The university will provide its Access For All curriculum, in an online format, to all community partners. The university will also share its peer mentoring curriculum and program and other resources relative to UED.

Students with disabilities in their last year of study at other IHEs will also be recruited to participate in the University DVR School to Work Transition program and external partner activities are ancillary to this project and will assist in forging alliances and building a foundation for expanded NSF efforts in the future. Project personnel will coordinate direct activities and evaluations. For participating EWU students, the project will coordinate their successful transition-to-college. Students will be given campus orientations, adaptive technology training, and referrals to the university Disability Support Services and the Counseling and Psychological Services Program (CAPS). They will be informed of university, state, and federal scholarships that are available for students in "high demand" disciplines. A DVR counselor will also meet with students and encourage them to consider applying for relevant DVR services. A peer mentor from the Disability Studies peer mentoring program course will be assigned to students. They will also be connected to mentors who are recipients of National Science and Mathematics Access to Retain Talent (SMART) grants. These student supports will be central in helping students to succeed at university and in developing the confidence and skills to succeed as STEM students. Students who receive peer mentoring will be recruited to become peer mentors to future incoming STEM students with disabilities to perpetuate peer mentoring in future classes. The transition resources that university will provide have been tied to increased retention rates for all students - especially for students with disabilities (Campbell \& Campbell ${ }^{4}$ 2007; Stumbo, Lindahl-Lewis \& Blegen ${ }^{13}$, 2008).

In the project's second year, activities will expand. Internal faculty and staff education will continue and collaborative relationships maintained and strengthened. The inaugural STEM Fair will be evaluated and modified by the Steering Committee. Recruitment and education will continue and expand. IHE faculty will again provide interactive projects in which students will participate. STEM Fair demonstrations will be expanded by inviting secondary school faculty 
and students to develop and present projects at the Fair. Area media outlets will be invited and the Steering Committee will create a judges panel that will award exemplary projects. These partner IHEs will also be invited to recruit potential STEM students with disabilities to their respective institutions.

Also in the second year, students and faculty from Washington's Central Valley, which has high numbers of low income, minority students will be recruited to attend the STEM Fair. In addition to secondary schools and IHEs, local tribes, migrant and seasonal farm worker organizations as well as faculty and staff from schools and organizations serving students with disabilities will participate to recruit students with disabilities to consider STEM. The project does not have sufficient resources to hold a second Fair in the Central Valley; however, project personnel will work with these organizations to organize one-day field trips to attend the Fair. The project will build partnerships in anticipation that future grants with expanded funding will provide resources to offer STEM Fairs in the Central Valley from Yakima to Tri-Cities. These Fairs will be modeled after the university main campus-based Fair, to refine activities and build a recruiting base for The university and allied IHEs such as Yakima Valley Community College and Columbia Basin Community College.

\section{Evaluation Methods}

The overriding goal for this project is to increase the number of students with disabilities enrolled in STEM programs. To reach this goal, four project objectives have been recognized. To evaluate the progress toward the objectives and overall project goal, seven assessment methods were established.

The objectives and assessment methods of the project are declared below. Each objective as outlined in Table 1 is stated along with the title of the assessment methods to be used. The assessment of each objective will have a triangulation using three assessment methods to ensure the validity of the total assessment of objective. An assessment report will be created at the end of each year of the project.

The purpose of the first year Continuous Improvement Report (CIP) will be to produce an improvement plan to be enacted in the second year to propose changes to the actions and plans to be used in the second year to improve and insure the successful attainment of the stated objectives of the program. A Project Steering Committee composed of members from all stakeholders shall review and approve the CIP report. The stakeholders on the CIP committee shall at a minimum include representation from each partner high school, each partner Community College, faculty representatives from EWU, EWU Department of Disability Services, EWU Department of Social Work, and the Co-Principal Investigators. The second year Continuous Improvement Report (CIP) will assess how well the project has met the stated objectives. In addition, the final CIP report will propose actions to ensure that the work of the project continues beyond the duration of this grant. 


\begin{tabular}{|c|c|}
\hline \multicolumn{2}{|c|}{$\begin{array}{l}\text { Goal: Increase the enrollment and retention of students with disabilities in STEM } \\
\text { Programs }\end{array}$} \\
\hline Objective & Assessment Methods (triangulated) \\
\hline $\begin{array}{l}\text { 1: Double the number of students with } \\
\text { disabilities who are declared majors in } \\
\text { STEM from } 16 \text { to } 32 \text { by increasing their } \\
\text { enrollment and retention. }\end{array}$ & $\begin{array}{l}\text { A: EWU database of declared majors } \\
\text { B: Survey of partner community colleges } \\
\text { C: Survey of partner high schools }\end{array}$ \\
\hline $\begin{array}{l}\text { 2: Improve the performance of students with } \\
\text { disabilities taking courses to match that of } \\
\text { students without disabilities in classes by } \\
\text { faculty who have attended the Access For All } \\
\text { training. }\end{array}$ & $\begin{array}{l}\text { D: EWU database of grades } \\
\text { E: Survey of students } \\
\text { F: Survey of Access For All professors }\end{array}$ \\
\hline $\begin{array}{l}\text { 3: Students who participated in project } \\
\text { activities will have a GPA } 0.3 \text { higher than } \\
\text { those students that did not participate. }\end{array}$ & $\begin{array}{l}\text { D: EWU student database of grades } \\
\text { B: Survey of partner community colleges } \\
\text { C: Survey of partner high schools }\end{array}$ \\
\hline $\begin{array}{l}\text { 4: } 85 \% \text { of the faculty who attend Access For } \\
\text { All training will incorporate UED principles } \\
\text { in their courses. }\end{array}$ & $\begin{array}{l}\text { E: Survey of students } \\
\text { F: Survey of Access For All professors } \\
\text { G: Syllabuses from Access For All } \\
\text { professors' courses }\end{array}$ \\
\hline
\end{tabular}

Table 1. Objectives and Assessment Methods

The seven assessment methods, Methods A through $\mathrm{G}$ as noted in Table 1, used to evaluate the identified objectives are described below. The specific data for many of these assessment methods are readily obtainable through the EWU Office of Student Records and are routinely collected following normal educational practices. This office maintains these data elements by individual student, by course, by course section, and by instructor. In addition, it is intended to analyze demographic variables including the students' race, gender, and identified major to determine the influenced results.

Assessment Method A: EWU Student Database of Declared Majors

The Advising Department of EWU currently keeps an electronic database of all students including their declared major. This database will be accessed and sorted for the target population of students (those with declared disabilities) to obtain the major for each student in the target population. This data will be obtained for each quarter of the school year before the project starts to obtain a baseline for comparison and then for each quarter during the project. This will provide a means of comparison of declared majors before, during, and at the end of the project.

Assessment Method B: Survey of Partner Community Colleges

Faculty and staff members from all participating Community Colleges in the STEM Fairs will be surveyed to determine the value of the Fairs and to promote collaboration and alliance building. The data collected will include: the type, amount, intensity, and magnitude of activities provided; 
the location and length of activities/workshop; the perceived interest of the student participants; and any suggestions for improvement.

Assessment Method C: Survey of Partner High Schools

Faculty and staff members from all participating High Schools in the STEM Fairs will be surveyed to determine the value of the Fairs and to promote collaboration and alliance building. The data collected will include: the type, amount, intensity, and magnitude of activities provided; the location and length of activities/workshop: the perceived interest of the student participants; and any suggestions for improvement.

\section{Assessment Method D: EWU Student Database of Grades}

Student performance data will be gathered from the EWU Student Database of Grades for courses taught by EWU STEM faculty members that have participated in the STEM Access For All program. The course grades and GPAs of students without disabilities will be compared to the course grades and GPAs of students with disabilities. In addition, student GPAs will be compared across comparable courses taught by the STEM faculty that participated in the STEM Access For All program versus those faculty members that did not.

\section{Assessment Method E: Survey of Students}

In order to measure the effect the STEM Fairs, mentoring, and Access For All training has had on the students with disabilities, each student will be surveyed before the STEM Fair. The purpose of this pre-survey will be to determine baseline knowledge of the student on their attitude toward STEM careers and how successful they feel they would be in a STEM curriculum in college. In addition, after attending the STEM Fair, mentoring program, and taking classes the student will be surveyed again on the same knowledgebase as the baseline survey. The difference in the surveys will be used to determine the extent that the STEM Fair, mentoring program, and Access For All training had on the students knowledge, awareness, and success in STEM careers. It will also denote how students with disabilities can successfully complete a college curriculum in STEM technology fields.

\section{Assessment Method F: Survey of Access For All Professors}

The faculty will be surveyed one year after attending a STEM Fair, mentoring program, and Access For All training to determine if they have altered how they teach their courses to be more inclusive for students with disabilities. These same faculty members will also be asked if they have noticed an increase in interest of students with disabilities in STEM fields.

\section{Assessment Method G: Syllabuses from Access For All training Professors' Courses}

The faculty that are to attend the Access For All training will be required to submit their current syllabus for each course that they actively teach along with a description of the modes and methods of instruction used. Six months after the training the faculty will again submit their current syllabus for each course that they actively teach along with a description of the modes and methods of instruction used. The pre and post training data collected will be reviewed by the project staff to determine the extent that the faculty member has changed what they are doing in the classroom as a result of the Access For All training received. 


\section{Conclusions, Reflection, and the Future}

This enrichment project will increase participation and success of students with disabilities at Eastern Washington University (EWU) in the fields of Science, Technology, Engineering and Mathematics (STEM) by focusing on recruiting high school and community college students with disabilities to enroll in STEM at EWU and at other institutions of higher education. Over the last two years, the number of students with disabilities at EWU has increased $50 \%$ to approximately 350 students; however, the number of STEM majors with disabilities has remained static. This project targets this critical academic area through faculty and staff training and student recruitment. EWU Alumni make up a significant portion of the regional workforce that continues to grow in the science, engineering, green technology, and biotechnology areas. This project will ultimately result in a more diverse, highly trained workforce.

It promotes the success of students with disabilities through direct interventions that encourage secondary students to consider STEM careers, providing readily applicable learning opportunities through STEM fairs as well as student supports. While STEM fairs are not novel, this project involves IHE partners and combines fairs with comprehensive supports that involve peer mentoring, academic advising, a multidisciplinary team, and external resources to promote student recruitment and retention. An important characteristic of this project is its emphasis on alliance building. This project is unique in that it uses a collaborative interdisciplinary approach between the School of Social Work and Human Services and the College of Science, Health \& Engineering at EWU. The Principal Investigators come from both of these areas.

This project will provide a foundation for altering intellectual culture in education for students with disabilities that can be sustained and enriched in the years following the project's completion as well as provide a foundation for a future NSF Alliance building project that will reach a broader audience.

\section{Bibliography}

1. Altshuler, S. A., Mackeiprang, R. W., \& Baker, R. L. (2008). Youth with disabilities: A standardized portrait of how they are faring. Journal of Social Work in Disability and Rehabilitation, 7 (1), 20-42.

2. Burgstahler, S. E., \& Cory, R. C. (Eds.). (2008). Universal Design in Higher Education. Cambridge, MA: Harvard Education Press.

3. Burgstahler, S. (1994). Increasing the Representation of People with Disabilities in Science, Engineering and Mathmatics. Retrieved January 28, 2009, from https://people.rit.edu/easi/itdvo $1 \mathrm{n} 4 /$ article9.htm

4. Campbell, T. A., \& Campbell, D. E. (2007). Outcomes of mdntoring at-risk college students: gender and ethnic matching effects. Mentoring and Tutoring, 12 (2), 135-148.

5. Center for Disability Studies and Universal Access. (2009). Washington State College SPARK. Improving the Success of Diverse Backgrounds, Final Report. Cheney, WA.

6. Center for Disability Studies and Universal Access. (2008). Report to US Department of Education on Improving the Quality of Education or Students with Disabilities at Eastern Washington University. Cheney, WA.

7. Lam, P., Doverspike, D., Zhao, J., \& Menzemer, C. (2008). An Evaluation of a STEM Program for Middle School Students on Learning Disability Related IEPs. Journal of STEM Education, 9 (1\&2), 2 1-29. 
8. Loendorf, W. R., Richter, D., \& Teachman, D., 2010: Results from an Interdisciplinary Service Learning Pilot Project Incorporating Universal Design Concepts for ADA Compliance, Proceedings of the American Society for Engineering Education (ASEE) Conference, Louisville, Kentucky, June 20-23, 2010.

9. Mackelprang, R. W., \& Altschuler, S. A. (2004). A youth perspective on life with a disability. Journal of Social Work in Disability and Rehabilitation, 3 (3), 39-52.

10. Mackelprang, R. W., \& Salsgiver, R.O. (2009). Disability: A Diversity Model Approach in Human Service Practice (2nd ed.). Chicago: Lyceum Books.

11. Melber, L. M., \& Brown, K. D. (2008). Not Like a Regular Science Class: Informal Science Education for Students with Disabilities. Clearing House, 1, 35-39.

12. Moriarty, M. A. (2007). Inclusive Pedagogy: Teaching Methodologies to Reach Diverse Learners in Science Instruction, Equity \& Excelence in Education, 40, 252-265.

13. Stumbo, N. J., Lindahi-Lewis, P.. \& Blegen, A. R. (2008). Two Mentorship Case Studies of High School and University Students with Disabilities: Milestones and Lessons. Journal of Rehabilitation, 74 (3), 45-51.

14. United States Census Bureau. (2007). American Fact Finder. Retrieved February 11,2009, from American Community Survey: http://factfinder.census.gov/servletlGCTTable?bm=y\&state=gct\&-context=gct\&dsname=AC 520073 Y R_G00_\&-

box head nbr=GCT $1701 \&$-mt name=ACS 2007 3YRGOOGCT 1701 ST2T\&- treeid=3307\&-redoLog=false\&caller=geoselect $\&$-geoid=04000US53\&-format=ST- 2 T\&-Iang=en

15. Washington Economic Development Commision. (2004, December 21). Washington Economic Development Commision Report to the Legislature. Retrieved February 11, 2009, from Community Trade and Economic Development:

http ://cted.wa.gov/CTED/documents/ID2o56Publications.pdf 